\title{
Effect of Plant Growth Regulators on Yield and Yield Attributing Character of Marigold cv. Calcutta Marigold under Konkan Conditions
}

\author{
T. T. Narute ${ }^{1 *}$, Y. R. Parulekar ${ }^{1}$ and T. K. Narute $^{2}$ \\ ${ }^{1}$ College of Horticulture, Dr. Balasaheb Sawant Konkan Krishi Vidyapeeth, Dapoli-415712, \\ District: Ratnagiri (M. S), India \\ ${ }^{2}$ Department of Plant Pathology, Mahatma Phule Krishi Vidyapith, Rahuri-413705, District: \\ Ahmednagar, Maharashtra, India \\ *Corresponding author
}

\section{A B S T R A C T}

\begin{tabular}{|l|}
\hline Ke y w o r d s \\
$\begin{array}{l}\text { Tagets erecta, Plant } \\
\text { growth regulators, } \\
\mathrm{GA}_{3}, \text { PGR, Flower } \\
\text { yield }\end{array}$ \\
\hline Article Info \\
\hline $\begin{array}{l}\text { Accepted: } \\
\text { 26 September } 2020 \\
\text { Available Online: } \\
10 \text { October } 2020\end{array}$ \\
\hline \hline
\end{tabular}

One of the commercially exploited flower crops belonging to the asteraceae family is Marigold. In many states, the commercial extraction of marigold carotenoids is currently becoming popular in our country. Proper crop management techniques are needed to produce cost-effective yields and improve the quality of marigold flowers. Number of harvestings manifest that the harvestings were not far from each other. The average number of harvestings resulted as non-significant. The range of harvestings was from 7.67 to 6.33. The number of flowers was significantly influenced by different growth regulators' treatment. The maximum average number of flowers per plant were recorded under the treatment $\mathrm{T}_{1}-\mathrm{GA}_{3} @ 100$ ppm (41.12), followed by $\mathrm{T}_{2}-\mathrm{GA}_{3} @ 200$ ppm (40.80). The yield of flowers per plant was differed due to the effect of plant growth regulators. As the PGR influenced the size and weight of flowers, the weight per plant ultimately was increased by treatment of $\mathrm{GA}_{3}$ and NAA. Maximum average yield per plant was noted in $\mathrm{T}_{1}-\mathrm{GA}_{3} @ 100$ ppm (424.83 g/plant). The yield per plant in $\mathrm{T}_{9}$ - Control recorded was $(387.17 \mathrm{~g} / \mathrm{plant})$. The flower yield per plot recorded was effectively influenced by application of PGRs. The yield per plant was increased which eventually increased yield per plot of $\mathrm{GA}_{3}$ and NAA treated plants. Maximum average yield was recorded in $\mathrm{T}_{1}-\mathrm{GA}_{3} @ 100$ ppm (12.74 kg/plot) treated plots. Flower yield was significantly influenced by different growth regulator treatments. Maximum average flower yield was observed under the treatment $\mathrm{T}_{1}-\mathrm{GA}_{3} @ 100 \mathrm{ppm}(20.98 \mathrm{t} / \mathrm{ha})$, followed by $\mathrm{T}_{2}-\mathrm{GA}_{3} @ 200$ ppm (20.76 t/ha).

\section{Introduction}

Marigold is one of the flower crops belonging to the asteraceae family and the Tagetes genus that are commercially exploited. The two key species that are popularly grown are Tagetes erecta L. and Tagetes patula L. in marigold, which originate in Mexico and South Africa, respectively. In Cochin (Kerala), Hyderabad (Andra Pradesh), Satyamangalam (Tamil Nadu) and Telagi, near Harihar, Davenagere, Haveri and Kolar, Chikmagalur district and 
around Bangalore (Karnataka), the commercial extraction of marigold carotenoids is currently carried out in our country. Consequently, large areas of marigold for xanthophyll extraction in Karnataka, Andra Pradesh, Tamil Nadu and Maharashtra are under contract farming. Proper crop management techniques are needed to produce cost-effective yields and improve the quality of marigold flowers. In order to make the production of the marigold profitable, crop control and flower forcing are effective techniques. By following pinching and application of PGRs, growth control can be achieved.

Depending on the variety cultivated, the response to these practises can differ. In order to optimise the yield of plants by modifying growth, development and stress behavior, plant growth regulators have gained broad acceptance (Shukla and Farooqi, 1990). When added exogenously to the plant, synthetic plant growth regulators such as auxins, cytokinins and various growth retardants influence different aspects of plant production and biosynthesis of its significant components (Kewalanand and Pandy, 1998). One of the most important functional aspects of the application of plant growth regulators is the regulation of flowering.

\section{Materials and Methods}

The present investigation was conducted during rabi season, of the year 2019-20 at Department of Floriculture and Landscape Architecture, College of Horticulture, Dr. Balasaheb Sawant Konkan Krishi Vidyapeeth, Dapoli to elucidate information on effect of different growth regulators on yield of marigold. This experiment was carried out in randomized block design (RBD) replicated thrice with 9 treatments. The crop African marigold variety Calcutta Marigold was taken for the study with the treatments.
The stock solution was prepared before actual application of treatments. For preparing 1000 $\mathrm{ml}$ of stock solution, $1 \mathrm{~g} \mathrm{GA}_{3}$ was added and dissolved in $10 \mathrm{ml}$ of $\mathrm{NaOH}$ solution and then this solution was transferred into one litre of volumetric flask and then total volume one litre was prepared with distilled water. For preparation of concentration of $100 \mathrm{ppm} \mathrm{\textrm {GA } _ { 3 }}$ solution, $100 \mathrm{ml}$ of stock solution was taken in volumetric flask and 1 lit volume was made up by using distilled water. By adopting similar procedure, the $200 \mathrm{ppm} \mathrm{GA}_{3}$ solution was prepared.

The remaining three plant growth regulators (PGR) were available in liquid form, therefore these were dissolved in distilled water. Accordingly, different concentrations were prepared.

The statistical analysis of data was done by adopting the standard statistical procedure given by Panse and Sukhatme (1967).

\section{Results and Discussion}

\section{Yield and Yield Attributing Parameters}

\section{Number of harvestings}

The data recorded on number of harvestings is presented in Table 1. The data collected perceived that the number of harvestings were not far from each other. The number of harvestings resulted as non-significant. The average range of harvestings was from 6.33 to 7.67 .

The more number of harvestings observed in $\mathrm{T}_{1}-\mathrm{GA}_{3} @ 100 \mathrm{ppm}$ (7.67) and was at par with $\mathrm{T}_{2}-\mathrm{GA}_{3} @ 200$ ppm (7.33), T 5 - CCC @ 4000 ppm (7.33), $\mathrm{T}_{6}-\mathrm{CCC} @ 5000$ ppm (7.00), T 4 -TRIA @ 30 ppm (6.67), $\mathrm{T}_{9}$ Control (6.67), $\mathrm{T}_{3}$ - TRIA @ 20 ppm (6.33), $\mathrm{T}_{7}$ - NAA @ 10 ppm (6.33), T - NAA @ 20 ppm (6.33). 


\section{Number of flowers per plant}

As marigold is a loose flower crop, individual flowers of each treatment were picked at proper stage and counted and the figures are presented in Table 10. The figures clearly represent that there was significant variation in number of flowers per plant among the different plant growth regulator treatments.

The maximum average number of flowers were recorded in $\mathrm{T}_{1}-\mathrm{GA}_{3} @ 100$ ppm (41.12) and $\mathrm{T}_{2}-\mathrm{GA}_{3} @ 200$ ppm (40.80) and both were on par. It was followed by $\mathrm{T}_{7}$ NAA @ 10 ppm (38.73), T8 - NAA @ 20 ppm (38.25), $\mathrm{T}_{9}$ - Control (35.60), these treatments were not statistically on par. The minimum number of flowers were observed in $\mathrm{T}_{3}$ - TRIA @ 20 ppm (28.90) and was at par with $\mathrm{T}_{4}$ - TRIA @ 30 ppm (28.42). The higher number of flowers is mainly due to production of more number of branches with good number of developed flowers on the branches. The flower yield per plant might be dependent on individual flower weight and number of flowers per plant leading to variation in flower yield among the different PGR treatments.

Similar results in flower yield were observed by Dabas (2000), Pandya (2000), Patidar (2003), Sunitha (2007), Naidu (2011), Kumar et.al. (2012), Dobaria (2012), Yadav (2013), Kumar (2017) with $\mathrm{GA}_{3}$ treatment. Markam, (2017) noted that in marigold the number of flowers per plant were increased with the application of $\mathrm{GA}_{3} 300 \mathrm{ppm}+\mathrm{CCC} 1500$ ppm.

TRIA recorded comparatively less number of flowers in this experimental trial. Skogen et.al., (1982), found that TRIA increased number of flowers in chrysanthemum. Deshmukh (2000) obtained more number of flowers with TRIA @ 1.25 ppm. Patidar (2003) noted that TRIA @ 2 ppm resulted in more number of flowers. Khandekar et al., (2013) evaluated that number of flowers were increased by TRAI treatment in Bougainvillea.

CCC data recorded in the present trial indicated that the number of flowers per plant were close to the readings that of control. Joshi (2004) and Kumar et al., (2011) observed that CCC @ 2000 ppm resulted more number of flowers per plant. Kumar (2006), Sunayana et al., (2017) put forth that the treatment increased number of flowers per lateral. In present trial, NAA resulted increased number of flowers per plant after $\mathrm{GA}_{3}$. Bairwa et al., (2017) recorded maximum number of flowers in NAA @ 300 ppm treated plants. Whereas, Jalagum (1991) recorded less number of flowers in marigold.

\section{Flower yield per plant (g/plant)}

The data pertaining to flower yield per plant showed significant effect of different plant growth regulators with different concentrations which is presented in Table 2.

Among all treatment effects, maximum average yield per plant was observed in $\mathrm{T}_{1}$ $\mathrm{GA}_{3} @ 100$ ppm (424.83 g/plant) which was at par with $\mathrm{T}_{2}-\mathrm{GA}_{3} @ 200$ ppm (420.44 g/plant), $\mathrm{T}_{7}$ - NAA @ 10 ppm (420.17 g/plant), $\mathrm{T}_{8}$ - NAA @ 20 ppm (418.17 g/plant), $\mathrm{T}_{9}$ - Control (387.17 g/plant), $\mathrm{T}_{3}$ TRIA @ 20 ppm (375.11 g/plant). The minimum flower yield per plant was observed in $\mathrm{T}_{5}$ - CCC @ 4000 ppm (318.67 g/plant) which was at par with $\mathrm{T}_{6}-\mathrm{CCC} @ 5000$ ppm (316.50 g/plant).

In the present investigation, significantly higher flower yield per plant was recorded under all concentrations of $\mathrm{GA}_{3}$ and NAA. This increased yield per plant over the control may be attributed to the fact that PGR treated plants became physiological more active to 
build up sufficient food stock which in turn promoted better plant growth with the result that more number of flowers were produced. The increase in yield might be due to direct growth regulating action of $\mathrm{GA}_{3}$. The presence of $\mathrm{GA}_{3}$ might have increased the growth promoting enzymes thereby manufacturing more nucleic acid, etc. in the plants. The findings were in accordance with the results of Patel (1998), Pandya (2000), Naidu (2011), Kumar etal. (2012), Dobaria (2012), Palei et al., (2016), Wadgave (2016), Markam, (2017) and Kumar (2017).

The yield obtained by TRIA in present experiment was non-significant, as the yield was not more than control treatment plots. On the contrary, Deshmukh (2000), Patidar (2003) reported that TRIA gave more yield among all the treatments in marigold.

The CCC reduced the yield per plant which might be the result of less number of branches, less number of bud initiation, flower size and minimum fresh flower weight. Aruna (1991), Nath (2005) and Naidu (2011) recorded more yield when treated with CCC which was contrary to the present results. The, NAA with two different concentrations also gave the significantly more yield of flowers. The probable reason may be due to increased plant height, more number of branches, more number of flowers and more fresh flower weight at its optimum concentrations. Similar results were also obtained by Patel (1998), Bairwa etal. (2017), while Aruna (1991) recorded less yield of flowers when treated with NAA.

\section{Flower yield per plot (kg/plot)}

The data noted on flower yield per plot influenced by plant growth regulators is presented in Table 3. Among all the growth regulator sprays, $\mathrm{T}_{1}-\mathrm{GA}_{3} @ 100$ ppm recorded significantly highest average flower yield per plot $(12.74 \mathrm{~kg} / \mathrm{plot})$ as compared to other treatments and which was on par with $\mathrm{T}_{2}-\mathrm{GA}_{3} @ 200$ ppm (12.65 kg/plot), $\mathrm{T}_{7}$ NAA @ 10 ppm (12.60 kg/plot), T - NAA @ 20 ppm (12.54 kg/plot). The treatments $\mathrm{T}_{3}$ TRIA @ 20 ppm (11.24 kg/plot), T 4 - TRIA @ $30 \mathrm{ppm}(11.20 \mathrm{~kg} / \mathrm{plot})$ and $\mathrm{T}_{9}$ - Control (11.17 kg/plot) were on par with each other. Minimum yield per plot was noted in $\mathrm{T}_{5}$ CCC @ 4000 ppm (9.56 kg/plot) which was on par with $\mathrm{T}_{6}-\mathrm{CCC} @ 5000$ ppm (9.48 $\mathrm{kg} /$ plot).

Table.1 Effect of plant growth regulators on average number of harvestings of marigold cv.

\section{Calcutta Marigold}

\begin{tabular}{|c|c|c|}
\hline Treatments & Treatment details & Average number of harvestings \\
\hline $\mathrm{T}_{1}$ & $\mathrm{GA}_{3} @ 100 \mathrm{ppm}$ & 7.67 \\
\hline $\mathrm{T}_{2}$ & $\mathrm{GA}_{3} @ 200 \mathrm{ppm}$ & 7.33 \\
\hline $\mathrm{T}_{3}$ & TRIA @ $20 \mathrm{ppm}$ & 6.33 \\
\hline $\mathrm{T}_{4}$ & TRIA @ $30 \mathrm{ppm}$ & 6.67 \\
\hline $\mathrm{T}_{5}$ & CCC @ $4000 \mathrm{ppm}$ & 7.33 \\
\hline $\mathrm{T}_{6}$ & CCC @ $5000 \mathrm{ppm}$ & 7.00 \\
\hline $\mathrm{T}_{7}$ & NAA @ $10 \mathrm{ppm}$ & 6.33 \\
\hline $\mathrm{T}_{8}$ & NAA @ $20 \mathrm{ppm}$ & 6.33 \\
\hline $\mathrm{T}_{9}$ & Control & 6.67 \\
\hline & Mean & 6.85 \\
\hline & S. Em. \pm & 0.44 \\
\hline & C.D. $\mathbf{a t} \mathbf{5 \%}$ & $\mathrm{NS}$ \\
\hline
\end{tabular}


Table.2 Effect of plant growth regulators on number of flowers per plant and flower yield per plant of marigold cv. Calcutta Marigold

\begin{tabular}{|c|c|c|c|}
\hline Treatments & Treatment details & $\begin{array}{c}\text { Average number } \\
\text { of flowers per } \\
\text { plant }\end{array}$ & $\begin{array}{c}\text { Average flower yield per } \\
\text { plant (g/plant) }\end{array}$ \\
\hline $\mathbf{T}_{\mathbf{1}}$ & $\mathrm{GA}_{\mathbf{3}} @ 100 \mathrm{ppm}$ & 41.12 & 424.83 \\
\hline $\mathbf{T}_{\mathbf{2}}$ & $\mathrm{GA}_{3} @ 200 \mathrm{ppm}$ & 40.80 & 420.44 \\
\hline $\mathbf{T}_{\mathbf{3}}$ & TRIA @ 20 ppm & 28.90 & 375.11 \\
\hline $\mathbf{T}_{\mathbf{4}}$ & TRIA @ $30 \mathrm{ppm}$ & 28.42 & 369.00 \\
\hline $\mathbf{T}_{\mathbf{5}}$ & CCC @ 4000 ppm & 30.05 & 318.67 \\
\hline $\mathbf{T}_{\mathbf{6}}$ & CCC @ 5000 ppm & 29.70 & 316.50 \\
\hline $\mathbf{T}_{\mathbf{7}}$ & NAA @ 10 ppm & 38.73 & 420.17 \\
\hline $\mathbf{T}_{\mathbf{8}}$ & NAA @ 20 ppm & 38.25 & 418.17 \\
\hline $\mathbf{T}_{\mathbf{9}}$ & Control & 35.60 & 387.17 \\
\hline & Mean & 34.62 & 383.34 \\
\hline & S. $\mathbf{E m} \mathbf{\pm}$ & 0.13 & 8.56 \\
\hline & C.D. $\mathbf{a t} \mathbf{5} \%$ & 0.40 & 25.65 \\
\hline
\end{tabular}

Table.3 Effect of plant growth regulators on flower yield per plot and flower yield per hectare of marigold cv. Calcutta Marigold

\begin{tabular}{|c|c|c|c|}
\hline Treatments & Treatment details & $\begin{array}{c}\text { Average flower yield } \\
\text { per plot (kg/plot) }\end{array}$ & $\begin{array}{c}\text { Average flower } \\
\text { yield per ha (t/ha) }\end{array}$ \\
\hline $\mathbf{T}_{\mathbf{1}}$ & $\mathrm{GA}_{3} @ 100 \mathrm{ppm}$ & 12.74 & 20.98 \\
\hline $\mathbf{T}_{\mathbf{2}}$ & $\mathrm{GA}_{3}$ @ 200 ppm & 12.65 & 20.76 \\
\hline $\mathbf{T}_{\mathbf{3}}$ & TRIA @ 20 ppm & 11.24 & 18.52 \\
\hline $\mathbf{T}_{\mathbf{4}}$ & TRIA @ 30 ppm & 11.20 & 18.22 \\
\hline $\mathbf{T}_{\mathbf{5}}$ & CCC @ 4000 ppm & 9.56 & 15.67 \\
\hline $\mathbf{T}_{\mathbf{6}}$ & CCC @ 5000 ppm & 9.48 & 15.62 \\
\hline $\mathbf{T}_{\mathbf{7}}$ & NAA @ 10 ppm & 12.60 & 20.73 \\
\hline $\mathbf{T}_{\mathbf{8}}$ & NAA @ 20 ppm & 12.54 & 20.64 \\
\hline $\mathbf{T}_{\mathbf{9}}$ & Control & 11.17 & 19.12 \\
\hline & Mean & 11.46 & 18.92 \\
\hline & S. $\mathbf{E m} \mathbf{\pm}$ & 0.23 & 0.42 \\
\hline & C.D. at 5\% & 0.70 & 1.26 \\
\hline
\end{tabular}

These results might be due to variation in production of flower yield as different growth regulators accelerate or decrease the metabolic process within the plants. Data recorded on flower yield per plot might have differed due to the effect of PGR to yield flowers. There was visible increase in yield of flowers in the plots treated with $\mathrm{GA}_{3}$. Similar results were obtained by Patel (1998), Pandya (2000), Naidu (2011), Kumar et al., (2012), Dobaria (2012), Palei et al., (2016), Wadgave (2016), Markam, (2017) and Kumar (2017). The plot yield of TRIA treatment was close to that of control plots. These results may be due 
to non-response of plants to the TRIA treatments. Deshmukh (2000), Patidar (2003) reported more yield in per plot treated with TRIA among all the treatments in marigold.

The size of the flower and the weight of the flower might be reduced due to the effect of cycocel which resulted in the reduced flower yield in per plot. However, Aruna (1991), Nath (2005) and Naidu (2011) observed maximum average yield per plot when treated with CCC as compared to other PGR treatments, which was contrary to the present results.

The yield per plot was significantly induced with two different concentrations of NAA. The observations close to the present trial data was also noted by Patel (1998), Bairwa et al., (2017). Although Aruna (1991) recorded less yield of flowers per plot when treated with NAA.

\section{Flower yield per hectare (t/ha)}

The treatment effect differed significantly for flower yield per hectare with range 15.62 to 20.98 tonnes per ha as shown in Table 3. The maximum average flower yield per hectare was recorded in $\mathrm{GA}_{3}$ treated plots followed by NAA.

Among all the treatment effects, maximum average yield per hectare was observed in $\mathrm{T}_{1}$ $\mathrm{GA}_{3} @ 100$ ppm (20.98 t/ha) which was at par with $\mathrm{T}_{2}-\mathrm{GA}_{3} @ 200$ ppm (20.76 t/ha), $\mathrm{T}_{7}$ - NAA@10 ppm (20.73 t/ha), T8 - NAA@ $20 \mathrm{ppm}$ (20.64 t/ha). The yield per hectare noted in further treatments were $\mathrm{T}_{9}$ - Control (19.12 t/ha) which was at par with $\mathrm{T}_{3}$ - TRIA @ 20 ppm (18.52 t/ha) and $\mathrm{T}_{4}$ - TRIA @ 30 ppm (18.22 t/ha). Minimum yield per hectare was recorded in $\mathrm{T}_{6}-\mathrm{CCC}$ @ 5000 ppm (15.62 t/ha) and was at par with $\mathrm{T}_{5}$ - CCC @ 4000 ppm (15.67 t/ha).
The increase in flower yield per ha might be due to increased flower weight and number of flowers per plant in respective treatment by the variety. Similar variation in flower yield after treatment of various plant growth regulators with different concentrations was also reported in past. The increase in flower yield per hectare with the treatment of $\mathrm{GA}_{3}$ was also supported with the results of Patel (1998), Pandya (2000), Naidu (2011), Kumar et.al. (2012), Dobaria (2012), Palei et. al. (2016), Wadgave (2016), Markam, (2017), Kumar (2017) in marigold plant.

The TRIA effect was not much significant in present trial which might be due to concentrations of TRIA used. The yield per hectare of TRAI treatment plants was recorded less as compare to control and other treatments. However, Deshmukh (2000), Patidar (2003) recorded increased yield in marigold with TRIA treatment. Wuryaningsih et al., (1997) recorded improved yield and quality in rose.

As the size and per flower weight was noted less, the yield per hectare was also recorded less in CCC treatment as compared to other treatments. Whereas, Aruna (1991), Nath (2005) and Naidu (2011) observed maximum average yield per hectare when treated with CCC as compared to other PGR treatments, which was converse to the present results.

It was significantly seen that NAA as growth regulator induced the number of branches, number of buds, weight of flower, flower size which simultaneously increased the yield per hectare. The present data recorded was close to the data noted by Patel (1998), Bairwa et al., (2017). Although Aruna (1991) recorded less yield of flowers per plot when treated with NAA. 


\section{References}

Bairwa, S. and Mishra, J. S. (2017). Effect of NAA, BA and Kinetin on yield of African marigold (Tagetes erecta L.), International Journal of Current Microbiology and Applied Sciences 6 (6). pp: 1236-1241.

Deshmukh, S.K. (2000). Effect of pinching and Triacontanol on growth, quality and yield of African Marigold (Tagetes erecta L.) cv. Pusa Narangi Gainda. Thesis Master of Science, J.N.K.V.V. Jabalpur. pgs. 112.

Dobaria, P. D., (2012). Effect of plant growth regulators on vegetative growth, flowering and yield of marigold (Tagetes erecta L.) cv. Pusa Narangi Gainda. M.Sc. Thesis JAU, Junagadh. $\mathrm{Pg}-116$.

Jalagum, A. (1991). Effect of plant growth regulators on growth, flowering and yield of marigold (Tagetes erecta L.). MSc. Thesis. Acharya N.G. Ranga Agricultural University, Rajendra Nagar, Hyderabad. pgs- 101.

Kumar, M. (2006). Effect of nutrients, pinching and growth retardants on growth, flowering and yield of African marigold (Tagetes erecta L.). Ph.D. Thesis. Chaudhary Charan Singh Haryana Agriculture University, Hisar. pgs -112 .

Kumar, M., Singh, A. K. and Kumar, A. (2012). Effect of plant growth regulators on flowering and yield attributes of African marigold (Tagetes erecta L.) cv. Pusa Naragi Gainda. Plant Archs., 14(1): 363-365.

Kumar, P. (2017). Effect of PGR's on growth, flowering and seed production in marigold cv. Pusa Narangi Gainda. Master of Science Thesis. Faculty of Post-Graduate Studies, She-e-Kashmir University of Agricultural Science and Technology-Jammu.
Markam, P. S. (2017). Studies on the effect of plant growth regulators on growth, flower yield and quality of African marigold (Tagetes erecta L.) under Chhattisgarh plains. PhD Thesis submitted to Indira Gandhi Krishi Vishwavidhyalaya, Raipur. 147 pgs.

Naidu, J. H. (2011). Effect of plant growth retardants, growth regulators and spacing on vegetative and flower yield of African Marigold (Tagetes erecta) cv. Pusa Narangi Gainda. Master of Science Thesis. Andhra Pradesh Horticultural University.

Nath, K. (2005). Effect of application of Maleic Hydrazide and Cycocel on the yield and quality of marigold (Tagetes erecta L.). Master of Science Thesis. Indira Gandhi Krishi Vishwavidyalaya, Raipur. pgs -86 .

Palei, S., Das, A. K., Dash, D. K. (2016). Effect of plant growth regulators on growth. flowering and yield attributes of African marigold (Tagetes erecta L.). International Education and Research Journal - 44., 2 (6).

Pandya, P. N. (2000). Effect of growth regulators on growth, yield and vase life of African marigold (Tagetes erecta L.) cv. 'Lemon Yellow'. MSc. Thesis. AAU, Anand. pgs - 73 .

Panse, V. G. and Sukhatme, P. V. (1995). Statistical methods for Agricultural Workers. ICAR publication, New Delhi.

Parihar, P. S. (2006). Effect of phosphorus and triacontanol on the growth, development and productivity of African marigold (Tagetes erecta L.) cv. Pusa Narangi Gainda.

Patel, J. K. (1998). Effect of plant growth regulators on vegetative and reproductive growth of French marigold (Tagetes patula L.) var. "Local". MSc. thesis. Department of Horticulture N. M. College of 
Agriculture, Navsari Agricultural University. Pgs -120 .

Patidar, D. (2003). Effect of triacontanol and gibberellin on the performance of African marigold (Tagetes erecta L.). M.Sc. Thesis, JNKVV, Jabalpur. pgs 114.

Singh, J., Nigam, R., Singh, R., Kumar, A. and Kumar, A. (2018). Effect of gibberellic acid and cycocel on growth, flowering and yield of chrysanthemum (Dendranthema grandiflora Ramat) cv. Birbal Sahni. Journal of Pharmacognosy and Phytochemistry,
SPI : $2753-2758$.

Wadgave, A. R. (2016). Effects of pinching and plant growth regulators on growth and yield of African marigold (Tagetes erecta L.) cv. Calcutta Orange in Krishna Command Area MSc thesis submitted to University of Horticultural Sciences, Bagalkot.

Wuryanigsih and Kusumo, S. S. (1997). Application of triacontanol to improve yield and quality of rose flower. Jurnal Hortikultura (Indonesia). 7(2): 673677.

\section{How to cite this article:}

Narute, T. T., Y. R. Parulekar and Narute, T. K. 2020. Effect of Plant Growth Regulators on Yield and Yield Attributing Character of Marigold cv. Calcutta Marigold under Konkan Conditions. Int.J.Curr.Microbiol.App.Sci. 9(10): 3998-4005.

doi: https://doi.org/10.20546/ijcmas.2020.910.459 